\title{
L'agiografia tra teorizzazione e pratica cultuale
}

L'hagiographie entre théorie et pratique cultuelle

Hagiography between Theory and Cultual Practice

\section{Paolo Odorico}

\section{(2) OpenEdition}

Journals

Edizione digitale

URL: http://journals.openedition.org/etudesbalkaniques/351

ISSN: 2102-5525

\section{Editore}

Association Pierre Belon

\section{Edizione cartacea}

Data di pubblicazione: 1 aprile 1994

Paginazione: $53-79$

ISBN: 2-910860-01-9

ISSN: $1260-2116$

\section{Notizia bibliografica digitale}

Paolo Odorico, «L'agiografia tra teorizzazione e pratica cultuale », Études balkaniques [En ligne],

1 | 1994, mis en ligne le 08 avril 2009, consulté le 29 avril 2019. URL : http://journals.openedition.org/ etudesbalkaniques/351

Questo documento è stato generato automaticamente il 29 aprile 2019

Tous droits réservés 


\section{L'agiografia tra teorizzazione e pratica cultuale}

L'hagiographie entre théorie et pratique cultuelle

Hagiography between Theory and Cultual Practice

\section{Paolo Odorico}

AUTORE

PAOLO ODORICO

Université de Trieste 